DOI: https://doi.org/10.24127/ajpm.v9i4.3003

\title{
PENERAPAN MODEL PEMBELAJARAN PENEMUAN TERBIMBING TERHADAP PENINGKATAN KEMAMPUAN PEMECAHAN MASALAH MATEMATIS MAHASISWA
}

\author{
Tahir $^{1 *}$, Prihadi Kurniawan ${ }^{2}$ \\ ${ }^{1 *}$ Universitas Sembilanbelas November, Kolaka, Indonesia \\ ${ }^{2}$ UIN Walisongo, Semarang, Indonesia \\ ${ }^{*}$ Corresponding author \\ E-mail: $\quad$ tahir.anwar.ta89@gmail.com ${ }^{\text {1*) }}$ \\ kurniawan.prihadi@walisongo.ac.id $^{2)}$
}

Received 29 July 2020; Received in revised form 15 December 2020; Accepted 27 December 2020

\begin{abstract}
Abstrak
Penelitian ini bertujuan untuk melihat bagaimana hasil penerapan model pembelajaran penemuan terbimbing terhadap peningkatan kemampuan pemecahan masalah matematis mahasiswa. Metode penelitian yang digunakan dalam penelitian ini adalah quasi eksperiment dengan desain non equivalent control grup. Dari hasil analisis deskriptif diperoleh dari 22 subjek kelas kontrol, rata-rata peningkatan kemampuan pemecahan masalah 0,25 dengan nilai terendah -0,66 dan tertinggi 0,69 serta standar deviasi 0,31 . Sedangkan dari 24 subjek pada kelas eksperimen, rata-rata peningkatan kemampuan pemecahan masalahnya 0,6 dengan peningkatan tertinggi 0,86 dan terendah 0,08 serta standar deviasi 0,24. Selanjutnya berdasarkan analisis inferensial yang dilakukan disimpulkan bahwa terdapat perbedaan yang signifikan peningkatan kemampuan pemecahan masalah matematis antara mahasiswa yang diajar dengan menggunakan model pembelajaran penemuan terbimbing dan mahasiswa yang diajar dengan menggunakan model pembelajaran konvensional. Dengan demikian penerapan model pembelajaran penemuan terbimbing lebih baik digunakan untuk meningkatkan kemapuan pemecahan masalah matematis mahasiswa khususnya pada matakuliah statistik matematika I.
\end{abstract}

Kata kunci: kemampuan pemecahan masalah; penemuan terbimbing.

\begin{abstract}
This research aims to see the results of the application of the guided discovery learning model in increasing students' mathematical problem solving abilities. The research method used in this research is Quasi experiment with non equivalent control group design. The descriptive analysis of 22 control class subjects shows the average increase in problem solving ability was 0.25 with the lowest value of -0.66 and the highest was 0.69 and a standard deviation of 0.31. Meanwhile, of the 24 subjects in the experimental class, the average increase in problem solving ability was 0.6 with the highest increase of 0.86 and the lowest 0.08 and a standard deviation of 0.24. Furthermore, based on the inferential analysis conducted, it is concluded that there is a significant difference in the improvement of mathematical problem solving abilities between students who are taught using the guided discovery learning model and students who are taught using conventional learning models. Thus the application of the guided discovery learning model is better used to improve students' mathematical problem solving abilities, especially in the mathematics statistics I course.
\end{abstract}

Keywords: guided discovery; problem solving ability.

This is an open access article under the Creative Commons Attribution 4.0 International License

\section{PENDAHULUAN}

Beberapa kajian-kajian tentang pendidikan, terutama kajian pendidikan matematika sepakat bahwa kurikulum dan pengajaran harus didasarkan dan dipusatkan pada cara siswa terlibat 
dalam penyelesaian masalah (Hiebert et al., 1996; Intaros et al., 2014; Schoenfeld, 2009). Di samping itu, kemampuan memecahkan masalah juga menjadi kompetensi yang harus dicapai peserta didik baik di penyelenggaraan satuan pendidikan dasar dan menengah atau pun di satuan pendidikan tinggi di Indonesia (Kemendikbud, 2013, 2020). Lebih lanjut, kemampuan pemecahan masalah menjadi salah satu kemampuan tingkat tinggi yang sangat dibutuhkan mahasiswa dalam mempelajari matematika (Andriani, 2017).

Namun, dalam praktik di perguruan tinggi, tingkat kemampuan pemecahan masalah yang dimiliki oleh mahasiswa masih terbilang rendah. Hal tersebut didasarkan pada hasil tes kemampuan pemecahan masalah pada mahasiswa program studi pendidikan matematika Universitas Sembilanbelas November Kolaka di mata kuliah Statistik Matematika II, yang diperoleh bahwa dari 51 mahasiswa terdapat 32 orang mahasiswa (lebih dari 60\%) yang memiliki kemampuan pemecahan masalah rendah. Selain itu, berdasarkan hasil wawancara dengan mahasiswa, kesulitan yang banyak dialami adalah proses memahami materi dan memecahan masalah.

Untuk mengatasi hal tersebut maka dibutuhkan suatu model pembelajaran yang dapat meningkatkan kemampuan pemecahan masalah mahasiswa. Salah satu model pembelajaran yang dapat digunakan adalah model pembelajaran penemuan terbimbing. Model pembelajaran penemuan terbimbing merupakan model pembelajaran yang dalam pelaksanaannya siswa berpikir kreatif sendiri sehingga dapat menemukan sebuah konsep, teori, pemecahan masalah, berdasarkan bimbingan atau arahan dari pengajar. Model penemuan terbimbing efektif untuk meningkatkan motivasi peserta didik, memberi ruang kepada guru untuk memberikan kesempatan kepada siswa untuk mencoba keterampilan baru, serta menumbuh peran siswa secara aktif untuk memahami konsep materi dengan pola pikirnya (Kasmini \& others, 2019; Khoiriyah, 2018).

Telah banyak dilakukan penelitian yang menerapkan model pembelajaran penemuan terbimbing dalam pembelajaran. Penelitian-penelitian tersebut mengerucutkan kesimpulan bahwa penerapan model pembelajaran penemuan terbimbing dapat meningkatkan hasil belajar matematika siswa (Maya et al., 2018; Mulyono et al., 2018). Selain berpengatuh terhadap hasil belajar, penerapan model pembelajaran penemuan terbimbing juga lebih baik dalam meningkatkan kemampuan konsep matematis siswa dibandingkan model pembelajaran konvensional (Romadon \& Mahmudi, 2019). Kemampuan pemahaman konsep matematika siswa dalam pembelajaran matematika dengan menggunakan model penemuan terbimbing juga secara keseluruhan berada pada kategori baik (Mawaddah \& Maryanti, 2016). Penerapan model pembelajaran penemuan terbimbing juga telah dilakukan di tingkat perguruan tinggi dan ternyata juga dapat meningkatkan dan hasil belajar mahasiswa dan berpengaruh positif terhadap prestasi belajar mahasiswa (Suryadinata \& Linuhung, 2018; Yulida et al., 2016).

Penelitian-penelitian yang telah dilakukan belum banyak yang membahas keterkaitan antara penerapan model pembelajaran penemuan terbimbing terhadap kemampuan pemecahan masalah matematis siswa, terutama siswa di jenjang perguruan tinggi. Karena itulah, penelitian ini bertujuan untuk mengetahui bagaimana 
hasil penerapan model pembelajaran penemuan terbimbing terhadap peningkatan kemampuan pemecahan masalah matematis mahasiswa.

\section{METODE PENELITIAN}

Penelitian ini merupakan penelitian quasi eksperiment. Desain penelitian yang digunakan adalah non equivalent control grup desain (Nurhasanah, 2014).

$\begin{array}{cccc}\mathrm{KE} & \mathrm{O}_{1} & \mathrm{X} & \mathrm{O}_{2} \\ \mathrm{KK} & \mathrm{O}_{3} & - & \mathrm{O}_{4}\end{array}$

Tahapan ini yaitu:

1. Memilih Kelas Eksperimen dan kelas kontrol

2. Memberi test awal berupa test kemampuan pemecahan masalah pada kelas eksperimen dan kelas kontrol yang digunakan sebagai data awal.

3. Memberi perlakuan berupa penerapan model pembelajaran penemuan terbimbing pada kelas eksperimen sedangkan pada kelas kontrol dilakukan seperti biasa. Perlakuan diberikan sebanyak 4 kali pertemuan

4. Melakukan test akhir pada kedua kelas.

5. Menghitung nilai peningkatan kedua kelas, dan selanjutnya dianalisis secara deskriptif dan inferensial.

Populasi dalam penelitian ini adalah semua mahasiswa program studi pendidikan matematika yang memprogram matakuliah statistik matematika II yang terdiri dari dua kelas dengan jumlah mahasiswa 48 orang. Sebaran populasi pada penelitian ini dapat dilihat pada Tabel 1 .
Tabel 1. Gambaran populasi penelitian.

\begin{tabular}{lcc}
\hline No & Kelas & Banyak Mahasiswa \\
\hline 1 & A & 22 \\
2 & B & 26 \\
\hline
\end{tabular}

Pemilihan sampel pada kuasi eksperimen dilakukan dengan teknik non random sampling sehingga teknik sampling yang digunakan adalah purposive sampling. Karena sampel yang dibutuhkan dalam penelitian ini adalah kelas kontrol dan kelas eksperimen, sehingga semua populasi menjadi sampel, dengan kelas A menjadi kelas kontrol dengan jumlah mahasiswa 22 dan kelas B menjadi kelas eksperimen dengan jumlah mahasiswa 26 orang.

Data pada penelitian ini dikumpulkan melalui 2 cara yaitu metode tes dan observasi, tes yang diberikan adalah tes esai yang telah diuji validitas, reabilitas, tingkat kesukaran dan daya pembedanya. Tujuan tes diberikan adalah untuk mengukur kemampuan pemecahan masalah matematis mahasiswa baik sebelum ataupun sesudah perlakuan. Sedangkan observasi dilakukan dalam bentuk lembar observasi, hal ini dalukan untuk melihat keterlaksanaan model pembelajaran maupun keaktivan mahasiswa dalam proses pembelajaran.

Analisis deskriptif dilakukan untuk memperoleh gambaran umum dari data penelitian. Dihitung nilai tertinggi, nilai terendah, jangkauan, nilai tengah, nilai yang sering muncul, rata-rata, varians, dan standar deviasi.

Peningkatan kemampuan pemecahan masalah matematis mahasiswa dihitung menggunakan rumus (1) normalisasi gain atau $N$-Gain. $g=\frac{\text { Nilai Post }- \text { Nilai Pre }}{\text { Nilai Max - Nilai Pre }}$

Klasifikasi N - Gain mengikuti Tabel 2. 
DOI: https://doi.org/10.24127/ajpm.v9i4.3003

Tabel 2. Klasifikasi N - Gain

\begin{tabular}{cl}
\hline N - Gain & Klasifikasi \\
\hline$g \geq 0,7$ & Tinggi \\
$0,3 \leq g<0,7$ & Sedang \\
$0<g<0,3$ & Rendah \\
$g=0$ & Tidak meningkat \\
$g<0$ & Menurun \\
\hline & (Tahir \& Marniati, 2020)
\end{tabular}

Analisis inferensial dilakukan untuk melihat perbandingan peningkatan kemampuan pemecahan masalah matematis mahasiswa yang diajar dengan menggunakan model pembelajaran penemuan terbimbing dan model pembelajaran konvensional.

Sebelum dilakukan uji hipotesis terlebih dahulu data yang diperoleh di uji prasyarat analisis yaitu uji normalitas dan uji homogenitas data. Setelah kedua uji tersebut terpenuhi maka dilanjutkan dengan uji $\mathrm{t}$ dengan rumus (2).

$$
t=\frac{\left(\bar{X}_{1}-\bar{X}_{2}\right)}{\sqrt{\frac{\left(n_{1}-1\right) s_{1}{ }^{2}+\left(n_{2}-1\right) s_{2}{ }^{2}}{n_{1}+n_{2}-2}\left(\frac{1}{n_{1}}+\frac{1}{n_{2}}\right)}}
$$

(Sugiyono, 2016)

Hipotesis yang diuji dalam penelitian ini adalah.

H0: $\mu_{1} \leq \mu_{2}$

$\mathrm{H} 1: \mu_{1}>\mu_{2}$

\section{HASIL DAN PEMBAHASAN}

Penelitian ini dilaksanakan tiga kali pertemuan untuk masing-masing kelas, dengan kelas B sebagai kelas eksperimen dan kelas A sebagai kelas kontrol.

Hasil Analisis Deskriptif Tes Kemampuan Pemecahan Masalah

Pada kedua kelas diberi tes di awal dan di akhir perlakuan untuk mengetahui peningkatan kemampuan pemecahan masalah matematis mahasiswa. Adapun hasilnya secara deskriptif dapat dilihat dalam Tabel 3 dan 4.

Tabel 3. Analisis deskriptif kelas kontrol.

\begin{tabular}{llll}
\hline $\begin{array}{l}\text { Statistik } \\
\text { deskriptif }\end{array}$ & $\begin{array}{l}\text { Pre } \\
\text { test }\end{array}$ & $\begin{array}{l}\text { Post } \\
\text { test }\end{array}$ & $\begin{array}{l}\text { N- } \\
\text { Gain }\end{array}$ \\
\hline$X_{\text {Max }}$ & 76 & 81 & 0,69 \\
$X_{\min }$ & 8 & 24 & $-0,66$ \\
$R$ & 68 & 57 & 1,35 \\
$M e$ & 29,5 & 46 & 0,26 \\
$M o$ & 22 & 44 & 0,63 \\
$\bar{X}$ & 32,64 & 51,77 & 0,25 \\
$S^{2}$ & 252,81 & 266.56 & 0,09 \\
$S$ & 15,9 & 16,33 & 0,31 \\
$n$ & 22 & 22 & 22 \\
\hline
\end{tabular}

Tabel 4. Analisis deskriptif kelas eksperimen.

\begin{tabular}{llll}
\hline $\begin{array}{l}\text { Statistik } \\
\text { deskriptif }\end{array}$ & $\begin{array}{l}\text { Pre } \\
\text { test }\end{array}$ & $\begin{array}{l}\text { Post } \\
\text { test }\end{array}$ & $\begin{array}{l}\text { N- } \\
\text { Gain }\end{array}$ \\
\hline$X_{\text {Max }}$ & 57 & 90 & 0,86 \\
$X_{\min }$ & 11 & 42 & 0,08 \\
$R$ & 46 & 48 & 0,78 \\
$M e$ & 30 & 75,5 & 0,67 \\
$M o$ & 32 & 75 & 0,77 \\
$\bar{X}$ & 30,5 & 73,15 & 0,6 \\
$S^{2}$ & 154,58 & 188,62 & 0,06 \\
$S$ & 12,43 & 13,73 & 0,24 \\
$n$ & 26 & 26 & 26 \\
\hline
\end{tabular}

Dari Tabel 3, diperoleh dari 22 subjek kelas kontrol, rata-rata peningkatan kemampuan pemecahan masalah 0,25 dengan nilai terendah 0,66 dan tertinggi 0,69 serta standar deviasi 0,31. Sedangkan dari Tabel 4, diperoleh dari 24 subjek pada kelas eksperimen, rata-rata peningkatan kemampuan pemecahan masalahnya 0,6 dengan peningkatan tertinggi 0,86 dan terendah 0,08 serta standar deviasi 0,24.

Selanjutnya hasil peningkatan kemampuan pemecahan masalah matematis mahasiswa diklasifikasi, 
DOI: https://doi.org/10.24127/ajpm.v9i4.3003

dengan hasil klasifikasi disajikan pada Tabel 5.

Tabel 5. Hasil klasifikasi nilai N-Gain kemampuan pemecahan masalah mahasiswa.

\begin{tabular}{|c|c|c|}
\hline \multirow[b]{2}{*}{ Kategori } & \multicolumn{2}{|c|}{ Frekuensi } \\
\hline & $\begin{array}{l}\text { Kelas } \\
\text { Eksperimen }\end{array}$ & $\begin{array}{l}\text { Kelas } \\
\text { Kontrol } \\
\end{array}$ \\
\hline Tinggi & 0 & 11 \\
\hline Sedang & 9 & 12 \\
\hline $\begin{array}{l}\text { Rendah } \\
\text { Tidak }\end{array}$ & 10 & 3 \\
\hline Meningkat & 0 & 0 \\
\hline Menurun & 3 & 0 \\
\hline
\end{tabular}

Hasil Analisis Inferensial

Uji Prasyarat Analisis

1. Uji normalitas

Uji normalitas data yang digunakan adalah uji kolmogorov smirnov dengan tingkat signifikansi $\alpha=5 \%$ (tabel 5) dan kriteria penolakan jika $D_{\text {hit }}<D_{\text {tab }}$ maka data berdistribusi normal. Hasil uji normalitas data dapat dilihat pada Tabel 6 .

Tabel 6. Uji normalitas data.

\begin{tabular}{lccl}
\hline Variabel & $\boldsymbol{D}_{\text {hit }}$ & $\boldsymbol{D}_{\boldsymbol{t a b}}$ & kesimpulan \\
\hline $\begin{array}{l}\text { kelas } \\
\text { eksperimen }\end{array}$ & 0,26 & 0,27 & Normal \\
kelas kontrol & 0,10 & 0,29 & Normal \\
\hline
\end{tabular}

2. Uji Homogenitas

Tabel 7. Uji homogenitas varians.

\begin{tabular}{lcccc}
\hline Variabel & $\boldsymbol{S}^{\mathbf{2}}$ & $\boldsymbol{F}_{\text {hit }}$ & $\boldsymbol{F}_{\text {tab }}$ & $\begin{array}{c}\text { Kesimp } \\
\text { ulan }\end{array}$ \\
\hline $\begin{array}{l}\text { Kelas } \\
\text { Eksperi } \\
\text { men }\end{array}$ & 0,06 & & & $\begin{array}{c}\text { Data } \\
\text { memilik }\end{array}$ \\
$\begin{array}{l}\text { Kelas } \\
\text { Kontrol }\end{array}$ & 0,09 & & & $\begin{array}{c}\text { i varians } \\
\text { yang } \\
\text { homoge } \\
\text { n }\end{array}$ \\
\hline
\end{tabular}

Uji homogenitas data yang digunakan adalah uji $\mathrm{F}$ dengan tingkat singnifikansi $\alpha=5 \%$ dan kriteria penolakan jika $F_{\text {hit }}<F_{\text {tab }}$ maka data homogen. Dari hasil analisis dapat dilihat pada Tabel 7.

\section{Uji syarat Analisis}

Dari uji prasyarat yang dilakukan, diperoleh hasil data berdistribusi normal dan homogen sehingga untuk pengujian hipotesis digunakan t-test Polled Varian dengan kriteria pengujian jika $t_{h i t}>t_{\text {tab }}$ tolak $H_{0}$ pada taraf signifikansi $5 \%$.

Tabel 8. Hasil uji t.

\begin{tabular}{lcrccc}
\hline Variabel & $\mathbf{n}$ & $\bar{X}$ & $\boldsymbol{S}^{\mathbf{2}}$ & $\boldsymbol{t}_{\boldsymbol{h i t}}$ & $\boldsymbol{t}_{\boldsymbol{t a b}}$ \\
\hline Kelas & & & & & \\
Eksperim & 26 & 0,6 & 0,0 & 4,4 & 2,0 \\
en & & 0 & 6 & 8 & 1 \\
Kelas & 22 & 0,2 & 0,0 & & \\
Kontrol & & 5 & 9 & & \\
\hline
\end{tabular}

Dari Tabel 8, dapat dilihat bahwa $t_{\text {hit }}=4,48$ dan $t_{\text {tab }}=2,01$ dalam artian $t_{\text {hit }}>t_{\text {tab }}$ sehingga dapat disimpulkan $\mathrm{H}_{0}$ ditolak, yang berarti rata-rata peningkatan kemampuan pemecahan masalah kelas eksperimen atau kelas yang diajar menggunakan model pembelajaran penemuan terbimbing lebih tinggi dari pada ratarata peningkatan kemampuan pemecahan masalah kelas kontrol atau kelas yang diajar dengan model pembelajaran konvensional.

Dari hasil deskripsi dan analisis data yang telah dilakukan, dapat dijelaskan pada kelas B digunakan sebagai kelas eksperimen dan kelas A sebagai kelas kontrol. Sebelum melakukan eksperimen kedua kelas terlebih dahulu diberi Pretest. Pretest dilakukan untuk mengetahui skor awal siswa sebelum diberi perlakuan. Dari 
DOI: https://doi.org/10.24127/ajpm.v9i4.3003

hasil pretest di kelas eksperimen diperoleh rata-rata nilai kemampuan pemecahan masalah matematis mahasiswa adalah 30,5 sedangkan di kelas kontrol rata-rata 32,64. Dari kedua nilai rata-rata tersebut dapat dilihat bahwa kemampuan pemecahan masalah matematis mahasiswa di kedua kelas masih kurang.

Sedangkan setelah melakukan perlakuan sebanyak empat kali pertemuan, mahasiswa kembali diberi test dalam hal ini post test. melalui hasil postest, diketahui bahwa hasil belajar kelas eksperimen setelah diberi perlakuan dengan penemuan terbimbing lebih tinggi daripada kelas kontrol yang menggunakan metode konvensional. Hal ini dilihat dari nilai rata-rata yang diperoleh kelas eksperimen adalah 73,15 dan rata-rata kelas kontrol adalah 51,77. Selanjutnya untuk melihat besar peningkatan kemampuan pemecahan masalah matematis kedua kelas, maka dihitung nilai $\mathrm{N}$-gain dan diperoleh hasil pada kelas kontrol nilai $\mathrm{N}$-gain atau nilai peningkatan kemampuan pemecahan masalah matematis mahasiswa berada pada range $-0,66$ sampai 0,69 dengan rata-rata 0,25 dengan rata-rata ini berada pada kategori rendah. Setelah mengkalsifikasin N-Gain yang disajikan pada Tabel 5, diperoleh pada kelas kontrol atau pada kelas diterapkannya pembelajaran konvensional, masih terdapat penurunan kemampuan pemecahan masalah matematis siswa yang mana bila kita lihat terdapat 3 mahasiswa, sementara nilai peningkatan tertinggi hanya berada pada kategori sedang, dengan rata-rata peningkatan berada pada kategori rendah.

Sedangkan pada kelas eksperimen peningkatan kemampuan pemecahan masalah matematis mahasiswa berada pada range
0,08 Sampai 0,86 dengan rata-rata 0,6 yang mana rata-rata yang diperoleh berada pada kategori sedang. Hasil ini menunjukkan bahwa pada kelas eksperimen semua peserta mengalami peningkatan kemampuan pemecah masalah matematis, yang mana apabila diperhatikan pada Tabel 5, peningkatan terbanyak berada pada kategori tinggi dengan 11 peserta dan rata-rata peningkatan kemampuan pemecahan masalah matematis pada kelas eksperimen berada pada kategori sedang.

Hasil analisis inferensial yang dicantumkan dalam Tabel 8 menunjukkan bahwa terdapat rata-rata peningkatan kemampuan pemecahan masalah kelas yang diajar menggunakan model pembelajaran penemuan terbimbing lebih tinggi dari pada ratarata peningkatan kemampuan pemecahan masalah kelas yang diajar dengan model pembelajaran konvensional. Hal ini menyebabkan untuk meningkatkan kemampuan pemecahan masalah matematis mahasiswa lebih baik jika diajarkan menggunakan model pembelajaran penemuan terbimbing. Hal ini dikarenakan mahasiswa pada model pembelajaran penemuan terbimbing mahasiswa aktif saat proses pembelajaran berlangsung. Peningkatan kemampuan pemecahan masalah matematis mahasiswa melalui penemuan terbimbing ini, disebabkan mahasiswa lebih antusias mengikuti pembelajaran seperti fokus lebih aktif dan kreatif dalam mengikuti kegiatan pembelajaran, siswa tidak lagi melakukan aktivitas diluar pembelajaran, mahasiswa semangat mencari jawaban dan berani menjawab pertanyaan tanpa dipanggil terlebih dahulu namanya kemudian menjelaskan kepada teman-temanya di depan kelas. 
Mahasiswa menjadi lebih aktif, termotivasi dan kreatif. Hal ini sejalan dengan pendapat (Khoiriyah, 2018) yang berpendapat melalui model pembelajaran terbimbing peserta didik dapat menumbuhkan perannya secara aktif, berpikir kritis, inovatif, dan peserta didik lebih bebas untuk memahami konsep materi menggunakan pola pikirnya. Berbeda dengan pembelajaran di kelas kontrol yang menggunakan metode konvensional, meskipun terjadi peningkatan dalam kemampuan pemecahan masalah matematis namun itu masih tergolong rendah, bahkan masih terdapat mahasiswa yang mengalami penurunan, hal ini dikarenakan masih banyak mahasiswa yang enggan bertanya dan memberikan pendapat, walaupun ada beberapa mahasiswa yang bertanya jika kurang mengerti dan Mahasiswa yang berani menjawab pertanyaan, mahasiswa yang pasif dalam pembelajaran ada yang tidak fokus dan ngobrol dengan teman sebangku atau teman dibelakangnya.

Hasil yang diperoleh pada penelitian ini sejalan dengan penelitian yang telah dilakukan (Yulida et al., 2016) dan (Suryadinata \& Linuhung, 2018) yang berkesimpulan bahwa penggunaan model pembelajaran penemuan terbimbing lebih baik dibandingkan penerapan model pembelajaran konvensional.

Dampak penelitian ini peningkatan kemampuan pemecahan masalah matematis mahasiswa berpengaruh baik pada penerapan model pembelajaran penemuan terbimbing karena peserta didik mengikuti proses pembelajarannya dengan motivasi yang baik, aktif serta kreatif hal ini sehingga peningkatan kemampuan pemecahan masalah matematisnya lebih baik dibanding mahasiwa yang diajar dengan model pembelajaran konvensional.

\section{KESIMPULAN DAN SARAN}

Berdasarkan analisis data baik secara deskriptif maupun secara inferensial yang dilakukan dapat disimpulkan bahwa terdapat perbedaan yang signifikan peningkatan kemampuan pemecahan masalah matematis antara mahasiswa yang diajar dengan menggunakan model pembelajaran penemuan terbimbing dan mahasiswa yang diajar dengan menggunakan model pembelajaran konvensional. Dengan demikian penerapan model pembelajaran penemuan terbimbing sangat baik digunakan untuk meningkatkan kemapuan pemecahan masalah matematis mahasiswa khususnya pada matakuliah statistik matematika I.

Untuk memperoleh hasil yang lebih baik lagi, maka dibutuhkan pernelitian lebih lanjut dengan membandingkan model pembelajaran terbimbing dengan model pembelajaran lain dengan memasukkan faktor-faktor pendukung lainnya dan pada matakuliah berbeda.

\section{DAFTAR PUSTAKA}

Andriani, A. (2017). Interaksi Antara Model Pembelajaran dengan Kemampuan Awal Matematika terhadap Peningkatan Kemampuan Pemecahan Masalah Matematik Mahasiswa FMIPA Pendidikan Matematika. Seminar Nasional Matematika (SEMNASTIKA). http://digilib.unimed.ac.id/id/eprint/2 6528

Hiebert, J., Carpenter, T. P., Fennema, E., Fuson, K., Human, P., Murray, H., Olivier, A., \& Wearne, D. (1996). Problem solving as a basis for reform in curriculum and instruction: The case of mathematics. Educational 
DOI: https://doi.org/10.24127/ajpm.v9i4.3003

Researcher, 25(4), 12-21.

Intaros, P., Inprasitha, M., \& Srisawadi, N. (2014). Students' problem solving strategies in problem solving-mathematics classroom. Procedia-Social and Behavioral Sciences, 116(1), 4119-4123.

Kasmini, L., \& others. (2019). Pengaruh Metode Penemuan Terbimbing Dalam Meningkatkan Kemampuan Berfikir Kritis Pada Pembelajaran Ipa Siswa Kelas IV SD Negeri 46 Banda Aceh. Tunas Bangsa Journal, 6(1), 115-128.

Kemendikbud. (2013). Peraturan Pemerintah Nomor 69 Tahun 2013 tentang Kerangka Dasar dan Struktur Kurikulum Sekolah Menengah Atas/Madrasah Aliyah.

Kemendikbud, D. D. (2020). Panduan Penyusunan Kurikulum Pendidikan Tinggi di Era Industri 4.0 untuk Mendukund Merdeka Belajar Kampus Merdeka.

Khoiriyah, S. N. A. (2018). Pengaruh Penggunaan Model Penemuan Terbimbing Terhadap Kemampuan Berpikir Kritis IPA. BASIC EDUCATION, 7(15), 1-427.

Mawaddah, S., \& Maryanti, R. (2016). Kemampuan pemahaman konsep matematis siswa SMP dalam pembelajaran menggunakan model penemuan terbimbing (discovery learning). Edu-Mat: Jurnal Pendidikan Matematika, 4(1).

Maya, Y., Ibrahim, L., \& Safrina, K. (2018). Penerapan model pembelajaran guided discovery learning (gdl) untuk meningkakan hasil belajar pada siswa smpn I bandar baru. Al-Khawarizmi: Jurnal Pendidikan Dan Pembelajaran Matematika, 2(2), 181-191. https://doi.org/http://dx.doi.org/10.2 2373/jppm.v2i2.4507

Mulyono, D., Purwasi, L. A., \& Riyadi, A. (2018). Penerapan Metode Penemuan Terbimbing pada Pembelajaran Matematika Siswa
SMP. JOEAI: Journal of Education and Instruction, 1(1), 51-58.

Nurhasanah. (2014). Pengaruh Gaya Belajar Terhadap Prestasi Belajar Matematika Siswa Kelas VII SMP Yapis Manokwari. Universitas Papua, 2(2), 173-182.

Romadon, S., \& Mahmudi, A. (2019). Penerapan pendekatan penemuan terbimbing untuk meningkatkan kemampuan pemahaman konsep matematis siswa. AKSIOMA: Jurnal Program Studi Pendidikan Matematika, 8(1), 58-64.

Schoenfeld, A. (2009). Learning to think mathematically: Problem solving, metacognition, and sense-making in mathematics. Colección Digital Eudoxus, 7.

Sugiyono. (2016). Satistika Untuk Penelitian. Alfabeta. Bandung

Suryadinata, N., \& Linuhung, N. (2018). Pengaruh Bahan Ajar Geometri Dasar Berbasis Penemuan Terbimbing terhadap Prestasi Belajar Mahasiswa. Kreano, Jurnal Matematika Kreatif-Inovatif, 9(2), 184-190.

Tahir, T., \& Marniati, M. (2020). Penerapan Metode Scamper Dalam Mengembangkan Kemampuan Pemecahan Masalah Ditinjau Dari Motivasi Mahasiswa Pendidikan Matematika Universitas Sembilanbelas November Kolaka. Jurnal SILOGISME: Kajian Ilmu Matematika Dan Pembelajarannya, 4(2), 43-48.

Yulida, R., Kausar, K., \& Andriani, Y. (2016). Penggunaan Model Pembelajaran Penemuan Terbimbing dalam Meningkatan Aktivitas dan Hasil Belajar Mahasiswa pada Matakuliah Penyuluhan dan Komunikasi Pertanian. MIMBAR PENDIDIKAN, 1(2), 189-200. 